\title{
Compulsory Education and the Tension Between Liberty and Equality: A Comment on Dworkin
}

\section{Peter M. Shane*}

Professor Dworkin's version of egalitarian liberalism is attractive on the two levels on which any worthwhile political philosophy must be attractive. First, it is centered on a powerful conception of a compelling moral ideal: equal concern and respect for the lives of all persons. Second, it helps to decide important cases. The ways in which Professor Dworkin asks us to understand equality and social justice often help steer us to persuasive and humane resolutions of disputes involving the use of state power.

Those sympathetic with Dworkin's understanding of equality will likewise applaud the ambition of his essay on liberty. In it, he seeks to unite the value of liberty with the value of equality in "a single humanist ideal."1 Should this ambition succeed, Dworkin would have assuaged a familiar liberal concern that allegiance to any robust conception of equality threatens society's fundamental commitment to liberty.

Professor Dworkin's theory of liberty, however, is not yet developed to the point where it is possible to be certain whether his ambition can be fulfilled in what he calls the "real real world."2 Despite Dworkin's efforts to clarify the relationship of liberty and equality under what he takes to be the best conception of the latter ideal, the tension between them still appears likely to bedevil the baseline choice or designation of the goods available for the auction that he uses to illuminate his conception of equality. ${ }^{3} \mathrm{~A}$ critical aspect of this choice for any society would be the determination whether parents may bid freely for control over the upbringing of their children, or whether a society committed to equal resources could justifiably limit parental choices in this respect. I do not perceive a way around the tension between liberty and equality in addressing this question, at least as Professor Dworkin's theory structures it. I would, therefore, like to set forth the dilemma by pursuing the problem of compulsory education as it would appear under the Dworkin model-not necessarily to invalidate his model, but as a challenge for its further refinement.

*Professor of Law, University of Iowa; A.B., Harvard, 1974; J.D., Yale, 1977. I would liké to thank Professors Martha Chamallas, Ken Kress, and William Buss for their helpful comments on this Essay.

1. Dworkin, What Is Equality? Part 3: The Place of Liberty, 73 Iow' L. REv. 1, 12 (1987).

2. Id. at 46.

3. Id. at 18 . 


\section{Recapitulating Dworkin's Model}

In two earlier articles, Professor Dworkin argued that the most adequate conception of distributive equality is the conception that he calls "equal resources." 4 Under this view, a society has distributed its goods justly if the distribution approximates the results of an auction in which each member of the society acquires a bundle of goods sufficient to meet the "envy test": "no one will envy the property assigned to or controlled by any other person."

Far from being antagonistic to this principle of equality, a commitment to liberty is necessary in order for the conception of equal resources even to be comprehensible. First, it is impossible for anyone bidding in the auction to evaluate the resources available for acquisition without "a liberty/constraint system," that is, a background set of standards stipulating "what one acquires in acquiring something at the auction." In other words, unless a person knows what uses of property are permissible or even protected from regulation, that person cannot make a sensible bid on that property. Second, it is impossible to evaluate the justness of any actual social distribution of property unless one can imagine an auction in which people bid under circumstances that permit the expression of authentic preferences. ${ }^{7}$ Dworkin argues that we can be confident of an authentic expression of preferences only if people are at liberty to form their personalities "authentically." This requires opportunities to "form and reflect on [one's] own convictions, attachments, and projects, and an opportunity to influence the corresponding opinions of others."8

These arguments persuasively establish Dworkin's thesis that liberty and equality have been perceived too readily as "independent and sometimes conflicting virtues," sometimes be made. He elaborates an attractive theory under which our understandings of liberty and equality are interdependent because some conception of liberty is necessary to render equality meaningful, and some background conception of social justice is necessary to render a set of liberty principles justifiable. For Dworkin, this conception is the principle of equal resources. ${ }^{11}$

Beyond this, however, one is not certain with Dworkin how much

4. Dworkin, What Is Equality? Part 1: Equality of Welfare, 10 PHIL. \&e PuB. AfF. 185 (1981);

Dworkin, What Is Equality? Part 2: Equality of Resources, 10 PHIL. \& PUB. AFF. 283 (1981).

5. Dworkin, supra note 1 , at 17-18.

6. Id. at 21 .

7. Id. at 2-3, 35-36.

8. Id. at 35 .

9. Id. at 3 .

10. Id. at 7 .

11. Dworkin states:

We hold two ideas in place: the abstract egalitarian principle, which demands equal concern, on the one hand, and equality of resources, which proposes that an auction under certain conditions realizes equal concern, on the other. . . . We select the baseline system that gives most plausibility to the claim that the auction from that baseline treats people with equal concern. Id. at 25. 
comfort to carry into the real world from the theoretical relaxation of tension between liberty and equality. At a number of points, he emphatically denies that they can conflict at the level of theory. He writes: "[T]he rights to liberty we regard as fundamental are a part or aspect of distributional equality, and so are automatically protected whenever equality is achieved."12 Later, he states that, because "liberty must figure in the very definition of an ideal distribution, .... there can be no problem of reconciling liberty and equality." 13 Yet, in Dworkin's real real world, tensions between liberty and equality may be frequently experienced. As Dworkin properly recognizes, no "actual society, whose citizens differ in productive capacities," can achieve the equal resources ideal that he describes. ${ }^{14}$ Therefore, societies committed to egalitarianism are presented constantly with the question whether constraints on liberty, not appropriate to an ideal set of baseline understandings of liberty, should be undertaken to produce a distribution of goods more equal and just than actually exists. ${ }^{15}$

Dworkin's response to this dilemma seems to be two-fold. First, he reminds us that the tension between libertarian and egalitarian ideals in the real world does not mean they conflict as ultimate ideals; "perfect equality," that is, still requires perfect liberty. ${ }^{16}$ This argument may be sound, but not altogether comforting. What troubles liberals, among others, is whether there can be commitments to robust conceptions of both liberty and equality in the real world, not just in principle. What matters most to our political lives is how our government behaves, not what it avowedly desires.

The second part of Dworkin's answer is that corrective constraints on liberty in the real world that are designed to help society achieve a better approximation of ideal equality do not compromise liberty as a social value so long as those constraints do not "victimize" any citizen - that is, so long as no one is made worse off in the name of equality than that person would be under any likely egalitarian distribution of goods in that society. ${ }^{17}$ If victimization is avoided, it is apparently Dworkin's view that a society can simultaneously preserve its fundamental commitments to liberty and to a just distribution of goods.

This answer is also incomplete. Imagine that I have more goods than I would have under any likely egalitarian distribution of social resources. Society now adopts constraints on my liberty designed to deprive me of unjust advantages derived from my surplus goods-constraints "[n]o plausible defensible distribution [of resources] would contain . ..."18 It is not clear why society is not abandoning its commitment to the fundamental status of liberty simply because I am not made worse off than I would be in any plausible egalitarian society. It might be argued that society does not abandon its commitment to liberty when it abandons the ideal rules of

12.Id. at 12 .

13. Id. at 13; see also id. at 24.

14. Id. at 18; see also id. at 43 n.34.

15. Id. at 47 .

16. Id.

17. Id. at $48-49$.

18. Id. at 46 . 
liberty in any case in which the implementation of those ideal rules is failing to produce as just a society as possible, measured by equality of resources. If so, then, as Professor Dworkin says in another context, "It will be cold comfort to those who love liberty to be told that equality demands liberty in some ideal world if they are also told that it may readily be sacrificed to equality here and now." 19 Alternatively, if adherence to a set of liberty principles is appropriate so long as they are soundly related in principle to an appropriate conception of equal concern for the lives of all citizens, then a society cannot abandon its liberty principles without thinking it is making a tradeoff between liberty properly understood and equality properly understood. For people who are living in the real world, that is what a tension between principles most importantly means.

Those passages in Professor Dworkin's essay in which he expressly considers whether liberty or equality is the paramount value provide little additional guidance on the real world relationship between those values. He states: "[M]y argument is not intended to subordinate liberty to equality." 20 Yet, it is hard to read Dworkin as not regarding liberty as essentially instrumental to equality and, in that sense, a subordinate value. Although Dworkin's strategy for conceptualizing equality presupposes some definition of liberty-and liberty, to that extent, is as fundamental as equality-the justification for any particular conception of liberty in Dworkin's view must be its service in the cause of rendering equality of resources the most defensible conception of equality. ${ }^{21}$ That is, liberty principles that do not serve his preferred conception of equality are to be rejected. Thus, equality seems to be the paramount ideal.

It may be that Dworkin would explain his stance by asserting that a proper conception of liberty is as important as the equal resources conception to achieving the abstract egalitarian principle of equal concern for all persons, but that the protection of liberty is subordinated to the redistribution of resources as a strategy for implementing equal concern for all persons in the real world. If so, then the practice of liberty and equality in an imperfect society must, for Dworkin, subordinate liberty to equality. Egalitarians must compromise liberty.

\section{COMPULSORY EduCATION}

Even if I am wrong that the tension felt in the real world between the goals of a just distribution of goods and of full adherence to a sound baseline system of liberties is a tension between liberty and equality in principle, such a tension seems to arise in the very elaboration of the baseline to Dworkin's imagined auction. To see this, consider how the problem of compulsory education must look from Dworkin's point of view.

Every state currently limits the liberty of parents to control the education of their children. In Dworlin's terms, each state limits the degree to which parents may bid on schooling resources for their children. The

19. Id. at 47 .

20. Id, at 12 .

21. Id. at 25 . 
typical requirement is that parents send their children to state-run schools unless the parents can provide an equivalent education, typically under the guidance of state-certified teachers in private institutions subject to state regulation. This constraint on parental liberty would apparently be justifiable under Dworkin's theory only if one of two conditions exists. First, it would be justifiable if a sound baseline system of liberties would not allow parents to bid for control over their children's education. Second, it would be justifiable if the constraint, although inconsistent with a sound baseline system, would nonetheless produce a more just distribution of actual social resources and parents would not be victimized by the degree of restraint imposed on their educational decision making.

\section{A. May Educational Control Be Auctioned?}

At first blush, it seems plain that Professor Dworkin supposes that a just egalitarian society would permit parents to bid freely for their children's schooling resources. His equality of resources conception generally prefers the fewest constraints on the use of resources because the absence of constraints promotes the flexibility of those resources over which people are bidding. ${ }^{22}$ What Dworkin calls the relative abstractness of the social auction permits that auction to register true opportunity costs more sensitively, thus yielding the most appealing results for all bidders. ${ }^{23}$

As Dworkin recognizes, however, the presumptive freedom from constraints that the principle of abstraction demands must give way when the absence of constraints would undermine other fundamental principles of liberty. This seems an especially pressing concern when the resources at issue involve educational control, because one can easily imagine educational control being used in ways that did undermine the principles of authenticity and independence, which Dworkin advances as fundamental. ${ }^{24}$ Thus, in deciding whether to permit bidding over schooling resources, society should consider with some care the likely impact on liberty that an auction over schooling resources would yield.

One possible defense of free bidding over schooling would focus on the liberty interests of children. If school-age children are not competent to make educational choices and parents are not permitted to make choices for them, then control over education will pass entirely to the state, with attendant risks to the principles of liberty that Dworkin identifies. Such a system, for example, might weaken existing constraints ${ }^{25}$ on the government's temptation to use schools for the inculcation of orthodox political beliefs, undermining the principles of authenticity and independence. That is, the state might promote a form of education akin to

22. Id. at 28.

23. Id.

24. Id. at 34-37.

25. For example, under the system of schooling that currently prevails in the United States, local boards of education presumably recognize that any attempt to promote forms of education grossly at odds with the views of great numbers of parents may prompt an exodus from the public system and a consequent threat to the community's willingness to support the public system through its taxes. This constraint operates even on boards of education that cannot be removed through local elections. 
brainwashing, undermining the children's ability as adults to express authentic preferences. ${ }^{26}$ Further, if brainwashed to be racists, the children would be unlikely to sustain the principle that requires them not to bid on goods out of prejudice or contempt for others. ${ }^{27}$ From this, it follows that parents should be able to bid on schooling resources, not in defense of their own liberty, but because they are the most trustworthy proxies for protecting the liberty of their not yet mature children.

An alternative defense of an unconstrained auction focuses on the importance of bidding on schooling to the liberty of the parents. Under Professor Dworkin's theory, any baseline liberty system designed to facilitate equality of resources must respect a principle of authenticity. According to that principle, an auction for goods is appropriate only under "some description of the circumstances in which people's personalities will be taken as properly developed"28 so as to permit the expression of people's authentic preferences. Authentic personality requires, in Dworkin's view, the capacity to form commitments, and this capacity can exist only in a society that permits one's convictions to be publicly expressed. ${ }^{29} \mathrm{~A}$ baseline system that accepts the principle of authenticity would thus protect people's "freedom to engage in activities crucial to forming and reviewing the convictions, commitments, associations, projects and tastes that they bring to the auction."

Although Dworkin does not say so, it seems undeniable that one way in which people form and review their convictions, commitments, projects, and tastes is through the auction itself. ${ }^{31}$ By purchasing goods, we state what we value, translate mere anticipation into actual experience, and subject our supposed agenda to examination by ourselves and by others. It may be, therefore, that Dworkin could buttress his presumption in favor of unconstrained choice because, to some extent, all resources facilitate self-expression and an abstract auction for resources thus promotes authenticity, as well as a true measure of opportunity cost. In American society, purchasing resources relevant to guiding the upbringing of one's child is an important means for the public identification of one's convictions. It follows that our baseline system of liberty should reject constraints on the auction for schooling resources because limiting parental choice over schooling is a constraint on that core experience of self-avowal.

The difficulty in accepting this argument based on parental liberty interests, of course, is that it ignores the interests of the child. Permitting parents full control over a child's education threatens the baseline system of liberty as it applies to the child. First, it is possible for parents-or any other

26. Dworkin, supra note 1 , at 35 .

27. Id. at 36 .

28. Id. at 35 .

29. Id.

30. Id.

31. For this reason, among others, I have trouble with the "fundamental distinction" Dworkin posits between a person and a person's circumstances, even in theory. Id. at 18-19. Professor Dworkin himself seems to recognize that personality will vary with circumstances. See $i d$. at 44 . On the other hand, it is questionable how much of Dworkin's theory truly depends on the distinction. 
agent-to choose an education that will significantly curtail the activities in which children could participate as adults. This would undermine the principle of abstraction to the extent it would reduce the children's flexibility in finding particular mixes of social resources that can be accurately fitted to their capacities. ${ }^{32}$ Second, it is possible for parents-or any other agent-to choose an education that will significantly curtail children's access to and ability to avow and to advocate a wide range of political or other opinions. This would undermine the principle of authenticity ${ }^{33}$ to the extent it would destroy our confidence in the ability of the children as adults to express their genuine preferences without unfair distortion.

A third problem, however, is perhaps the most telling. Parents-or any other agent-may choose an education for children that promotes contempt or strong disapproval for others who reject the parents' value commitments. They may choose, for example, a racist form of schooling. Such choices would indirectly threaten the principle of independence by making it less likely that society would be able to sustain over time a distribution of goods that is not based on prejudice or animus. ${ }^{34}$

32. Dworkin demonstrates that the principle of abstraction has implications not only for the forms in which goods should be auctioned, e.g., clay, but also for the liberty system that conditions their use, e.g., legal protection for the right to sculpt satirically. Id. at 21, 29. On this ground, abstraction also requires that people be sufficiently trained to make use of available resources to suit their projects.

It would not seem to be enough to make compensatory education available to grown children who have been subject to constricting forms of schooling that undermined abstraction because that would require those children to devote their resources to reaching what should have been their baseline entitlement. Cf. id. at 24.

33. Id. at 34-35.

34. I have argued elsewhere that maintaining what Dworkin calls the principle of independence may be the strongest ground for supporting some form of government control over education. "[T] he most compelling reason for permitting government to require children to spend large parts of their early lives in predominantly government-run institutions may be the critical importance of schooling to social integration." Shane, School Desegregation Remedies and the Fair Governance of Schools, 132 U. PA. L. REv. 1041, 1126 n.264 (1984).

Dworkin's current essay is not altogether clear on how the principle of independence is to be protected in practice. Under his ideal, the success anyone would have at the life he or she proposes would depend on the opportunity costs others bear from that life, given their own, different plans. $C f$. Dworkin, supra note 1 , at 30 . This version of neutrality among bidders on goods extends to "each person's social requirements - the social setting he claims he needs in order successfully to pursue his chosen way of life ." Id. at 31. Thus, a person whose life plan requires a religiously intolerant society will find that life unavailable under equality of resources because it costs too much in terms of the opportunity costs other members of society would be willing to forgo. It seems, in other words, that it is the plural desires of society's members that ultimately protect the principle of independence.

In illustration of the point, Dworkin thinks it likely that the intolerant would be able to afford islands of intolerance in an otherwise tolerant society, id. at 31, and regards it as "incredible" that any group in society "could buy resources of such breadth and scope that . . . a member of a minority religion [would] not be left free to practice his religion." Id. at 34 .

I am not sure why Professor Dworkin is so confident on this point. If, for example, the religious convictions of a citizen of the United States require him or her to be educated in a racially exclusive group setting, there (happily, from my point of view) seems no way to ensure that such an opportunity can be made available, irrespective of the resources that religious racists are willing to devote to the practice of their beliefs. See Runyon v. McCrary, 427 U.S. 160 (1976). 
The sets of educational choices that I have posited, each potentially destructive of the system of liberty as it protects children, would seem also to render it less likely that the children, as adults, will enjoy the equality of resources Dworkin embraces. ${ }^{35}$ Indeed, these threats to the equality of future adults would seem to exist even if the children themselves were able to bid on education. If, for example, students themselves preferred racist schooling, that choice might undermine the principle of independence, in which case the tradeoff facing society would be between the liberty of racist students and the prospects of social equality for others in the long run. If this is so, then a clear tension exists between demands for liberty and demands for equality, as they are implicated by the auction of schooling resources, whether we think of schooling as involving the liberty interests of students, parents, or both.

Dworkin's response might be that this poses the dilemma misleadingly because I have referred to bidding over educational control in an undifferentiated way, as though whether to permit such bidding was a simple "either/or" choice. It might be argued that the correct approach is to differentiate among aspects of educational control, those that the state must withhold from parental (or student) bidding in order to protect the equality of resources and those that must remain subject to bidding in order to further the principles of liberty.

One form of such balancing is, in fact, what we have as a result of Pierce v. Society of Sisters, ${ }^{36}$ which prohibited state insistence on education in state-run schools, but approved in dicta a state's regulation of schooling with respect to teacher qualifications and the core curriculum. ${ }^{37}$ This balancing, however, does not eliminate the conflict between liberty and equality as values. No matter how important it might seem that the state should be able to insist on controlling some aspect of a child's educationin order to protect equality of resources in the next generation-that insistence is a partial constraint on the parent's ability to profess certain commitments through the upbringing of children or on the child's ability to express his or her commitments through educational choice. Conversely, no matter how important it might seem that parents should be able to insist on controlling some aspect of their children's education-in order to protect their liberty interests or those of their children-that parental control threatens to sacrifice the equality rights of future generations. Thus, it is not easy to see how the decision whether to include any aspect of educational control in society's auction can be made without confronting a tension in principle between liberty and equality.

35. For purposes of this discussion, I am treating the state as protecting the child's interests. Children, of course, eventually reach a stage of maturity at which it is possible for them "authentically," to use Professor Dworkin's phrase, to prefer the form of education for themselves that their parents would have chosen. To the extent that the preferences of parents who dissent from the state design for education would be aligned with the preferences of their children, there would still seem to be a potential conflict between the liberty of the children and the general prospect of society maintaining its commitment to the independence principle.

36.268 U.S. 510 (1925).

37. Id. at 534 . 


\section{B. If Auctioned, May Educational Control Be Constrained?}

My analysis so far has discussed educational liberty and constraints on that liberty against the background of Dworkin's ideal world. Perhaps I am underestimating the degree to which the problem can be worked out in practice. Dworkin might suggest that a state educational system could be designed consistent with fundamental principles of liberty if it created as much educational choice as would exist in any likely egalitarian society, even though parents were constrained to operate within the state system. ${ }^{38}$

Such a suggestion, however, would be problematic at two levels. First, to perceive the set of all likely egalitarian distributions, one must be able to perceive in advance the system of liberties on which such distributions would be based, including the goods that would be available for auction. This, however, simply returns our attention to the tension-laden relation already discussed between parental liberty and child equality. The range of plausible egalitarian distributions of schooling resources cannot be imagined unless we can specify which aspects of control over schooling would be available for bidding in the ideal auction.

Second, the determination of plausible and defensible egalitarian societies against which to measure the permissibility of real-world liberty constraints is a process of "counterfactual speculation."39 I agree with Professor Dworkin that we can confidently engage in some such speculation, determining, for example, that the current distribution of campaign resources in the United States could not fit any such scheme.40 On particular issues of educational control, however, the strategy is much less promising. To use Professor Dworkin's phrase, a prediction of what egalitarian societies would permit regarding education seems to be just the

38. Another way of putting the point I am exploring here follows from Professor Dworkin's distinction, in an earlier work, between "abstract rights" and "concrete rights":

An abstract right is a general political aim the statement of which does not indicate how that general aim is to be weighed or compromised in particular circumstances against other political aims. ...

Concrete rights, on the other hand, are political aims that are more precisely defined so as to express more definitely the weight they have against other political aims on particular occasions.

R. DWORKIn, TAKing Rights Seriously 93 (1978). Using these terms, my hypothesized strategy for resolving the tension between liberty and equality may be articulated as follows: "Liberty" and "equality" may seem to conflict when considered as "abstract rights," but, properly understood, they provide arguments for "concrete rights" to liberty and equality that are not in tension.

In fact, this does not appear to be Dworkin's position, because of his argument that the abstract liberty principle is built into the abstract principle of equal resources. Dworkin, supra note 1 , at 12,24 . In any event, the point of my discussion is that, even if the tension between liberty and equality can be worked out at the level of concrete rights, Dworkin does not clarify how the leap is to be made from "abstract" to "concrete."

39. Dworkin, supra note 1 , at 38 .

40. Id. at 49. I agree with Professor Dworkin's dissection of Buckley v. Valeo, 424 U.S. 1 (1976). I believe, furthermore, that Buckley is a repudiation of the egalitarian ideal behind the Federal Election Campaign Act. In determining the unconstitutionality of the Act's restrictions on independent expenditures, the Court wrote: "[T] he concept that government may restrict the speech of some elements of our society in order to enhance the relative voice of others is wholly foreign to the First Amendment . . . " 424 U.S. at 48-49. 
"whistling-in-the-dark act of faith" he criticizes in utilitarian attempts to reconcile liberty and equality. ${ }^{41}$ It may be my failure of imagination, but I see no reasonable hope of analysis, reflection, and speculation guided by Dworkin's model yielding any more of a consensus finding in this respect than analyses based on utilitarian or welfare-egalitarian principles. The desired conclusion sounds as if it is empirically based, but there are no data subject to uncontroversial interpretation upon which to reach such a judgment.

Consider, for example, a quite straightforward case: the metropolitanization of student school assignments. Imagine that the State of Texas passed a law requiring all students in the San Antonio metropolitan area to attend a school of the State's choice, in order to reduce resource inequality between urban ghettos and wealthy suburbs. The egalitarian defense of such a law need hardly be elaborated here. Could it be determined, however, whether excluding parental choice over the locale of a child's school leaves the parent no worse off than he or she would be given the most likely set of egalitarian distributions of social resources? I do not see how.

\section{Other Directions}

It may be that I have somehow misconstrued Dworkin's argument or that its elaboration or qualification would diminish my sense that the tension between liberty and equality remains. It may also be that the tension cannot be tamed any more successfully under any other liberal theory than Dworkin has managed to accomplish. It seems worth noting, however, that Dworkin has avoided one obvious direction that many have thought promising in this respect. He has adopted one conventional view of liberty that regards liberty only in a negative way, as the absence of constraint. 42 One wonders whether a more substantive or affirmative account of liberty would do better-an account, for example, in which some degree of equality would be necessary even to speak of liberty as a real thing. For example, should we think that a drastically impoverished person has liberty even in principle if he or she lacks resources to bring into reality any personal commitment or ambition? ${ }^{43}$

I do not mean to hint that I have any rigorous alternative theory in mind or would prefer it to Dworkin's. It may be that equality and liberty are

41. Dworkin, supra note 1 , at 11 ; see also $d$. at 16 (contractarian assumption that people would prefer to have liberty in a just society "scems another whistling-in-the-dark act of faith").

42. Id. at 1 .

43. Dworkin's wholly negative description of liberty is consistent with the distinction he draws between human "personality" and human "circumstances." This distinction makes it possible to speak of "authentic personality" developing and demanding protection irrespective of access to resources. There is a humane aspect to this attitude because it accepts that all persons, no matter what their station in life, have the possibility of authentic personality. It seems clear, however, that one's expression of personality is profoundly related to circumstances, and that more generous circumstances often permit people to express themselves in ways that may be fundamental to their character, but which would be hidden, even perhaps to themselves, in poorer circumstances. I suspect Dworkin agrees with these points; I am not certain how they fit with his theory. 
inexorably in tension and persuading ourselves otherwise would lead us too easily to devalue the preservation of either. Ideally, our conscious inability to enjoy either liberty or equality to the ideal extent should lead us to yearn for more of both and to guard what we have with due vigilance. 
